\title{
Comparative Immunology of Ribosomes and Disc Gel Electrophoresis of Ribosomal Proteins from Erwiniae, Pectobacteria, and Other Members of the Family Enterobacteriaceae
}

\author{
NORMAN W. SCHAAD \\ University of Georgia, College of Agriculture Experiment Stations, Georgia Station, \\ Experiment, Georgia 30212
}

\begin{abstract}
Ribosomes from erwiniae, pectobacteria, and other Enterobacteriaceae were compared by two criteria: (i) disc gel electrophoresis of $50 S$ subunit proteins, and (ii) Ouchterlony gel diffusion of intact ribosomes. There were no significant differences in the electrophoretic protein profiles of strains of Escherichia coli, Salmonella typhimurium, Klebsiella pneumoniae, or Enterobacter agglomerans (synonym: Erwinia herbicola). The only signficant profile differences occurred with the faster-migrating proteins of enterobacteria grouped according to plant or animal source. Several non-enterobacteria also had similar over-all profiles; however, specific differences were evident. Immuno-diffusion data were effective in establishing relatedness at the subspecies level. A single antigenic determinant was responsible for the specificity and was found to differ in its sensitivity to treatment with trypsin, ribonuclease, or heat.
\end{abstract}

Results of investigations on the structure and function of ribosomes suggest the possibility of using ribosomes to determine phylogenetic relationships of bacteria. All bacterial ribosomes studied have subunits with similar sedimentation coefficients, ribonucleic acid species, and amounts of protein $(28,43)$. Ribosomal proteins are heterogenous $(13,21,46)$, direct products of structural cistrons $(36,37,44)$ and exhibit sequence and charge similarities between closely related species $(21,45)$. On the other hand, distantly related species have ribosomal proteins of similar molecular weights (41). Thus far, however, no single method of analysis has proven completely satisfactory in expressing comparative similarities or differences.

Preliminary studies of subunit proteins by column chromatography (27) or total proteins by one-dimensional acrylamide gel electrophoresis (19) have shown that protein profiles from closely related bacteria exhibit more similarities than do profiles from distantly related bacteria. In fact, 60 strains of Escherichia coli have been classified into seven groups according to their subunit protein composition (26). These methods have several disadvantages: accurate, unbiased comparisons are difficult; slight variability can occur between analyses; single bands often consist of more than one protein; and it has been difficult to infer any relationship between proteins from two differ- ent ribosomes except when they are identical. The single-band problem has been solved by the two-dimensional gel electrophoresis technique (20); however, the other problems have not. The problems associated with analysis of total or subunit proteins suggested investigating not only the individual components but also ribosomal topography. Several studies have been initiated recently to determine the topography and intimate structural arrangement of $E$. coli subunit ribosomes $(5,6,9,14,22)$. Based on trypsin sensitivity and gel electrophoresis, these studies have indicated that proteins are more exposed than ribonucleic acid (RNA) in the $30 \mathrm{~S}$ subunit, with the reverse being true for the $50 \mathrm{~S}$ subunit. I have used a more direct method, that is, immunology, to study the topography of intact ribosomes. Immunological techniques are not new to ribosomal investigations; immunology has been used to substantiate the heterogeneity of subunit proteins $(11,39,40)$ and the interrelatedness of ribosomal structure and function (14). In a preliminary study, Quash et al. (31) showed that intact ribosomes were immunologically species specific, and Friedman et al. (14) demonstrated that $E$. coli $50 S$ split-protein antiserum reacted only with enterobacterial ribosomes. Subsequently, however, intact ribosomes (24) and subunit proteins (49) have been shown to cross-react with those of unrelated microorganisms.

The purpose of this work was to use two 
independent approaches to study the interesting and important problem of relatedness between closely and distantly related bacterial ribosomes. I have analyzed intact ribosomes by Ouchterlony double-diffusion and $50 S$ subunit proteins by disc gel electrophoresis from several isolates of five members of the family Enterobacteriaceae plus several other gram-negative rods. A gram-positive coccus was also used for Ouchterlony double-diffusion tests. The family Enterobacteriaceae was chosen because of the voluminous taxomonic and genetic information available for comparing results and because of the recent association of Enterobacter agglomerans Ewing and Fife (synonym: Erwinia herbicola) with human infections $(12,15,21$, $23,47)$. Recent genetic studies have shown the close relationship of erwiniae to other Enterobacteriaceae $(4,7)$.

\section{MATERIALS AND METHODS}

Bacterial strains and preparation of cells. The bacterial strains used in this study are listed in Table 1. Bacteria were maintained on yeast extract-dextrosecalcium carbonate agar and cultivated in medium 523 (19) at $36 \mathrm{C}$ in 2.4-liter Fernback flasks on a rotary shaker. Early log-phase cells (Klett reading of 30 to 50 ) were harvested by centrifugation in a refrigerated Sorvall RC2-B centrifuge with a GSA rotor at 10,000 $\mathrm{rpm}$ for $10 \mathrm{~min}$. The pellet was washed overnight in $0.85 \% \mathrm{NaCl}$, recentrifuged, and stored frozen.

Preparation of ribosomes. Ribosomes were obtained from 2 to $5 \mathrm{~g}$ (packed wet weight) of cells. The cells were suspended at $10 \mathrm{C}$ in 10 volumes of $\mathrm{TKM} / 3$ buffer $[0.01 \mathrm{M}$ tris(hydroxymethyl)aminomethane

TABLE 1. Bacterial strains ${ }^{a}$

\begin{tabular}{|c|c|c|c|c|}
\hline \multicolumn{2}{|c|}{ Strain } & Origin & \multirow[t]{2}{*}{ Date } & Source \\
\hline Escherichia coli & 01a (Antigen type) & Pig & & Ewing, CDC \\
\hline E. coli & $01 \mathrm{~b}$ (Antigen type) & Pig & & Ewing, $\mathrm{CDC}$ \\
\hline E. coli & 02a (Antigen type) & Pig & & Ewing, CDC \\
\hline E. coli & $02 \mathrm{~b}$ (Antigen type) & Pig & & Ewing, CDC \\
\hline E. coli & 04 (Antigen type) & Pig & & Ewing, CDC \\
\hline E. coli & 06 (Antigen type) & Standard Strain & & Ewing, CDC \\
\hline Salmonella typhimurium & 13311 (ATCC) & Human & & Roach Diagnostic Lab \\
\hline S. typhimurium & 4066 & Human & & Ewing, CDC \\
\hline S. cholerae-suis & 1348 & Pig & & Ewing, CDC \\
\hline Klebsiella pneumoniae & 15 & Human & & Ewing, CDC \\
\hline K. pneumoniae & 20 & Human & & Ewing, $C D C$ \\
\hline K. pneumoniae & 30 & Human & & Ewing, CDC \\
\hline Pectobacterium carotovora & 14 & Calla & 1946 & Dickey, Cornell \\
\hline P. carotovora & 34 & Iris & 1946 & Dickey, Cornell \\
\hline P. carotovora & 105 (ICPB) & & & Goodman, Missouri \\
\hline P. carotovora & 150 (ICPB) & & & Goodman, Missouri \\
\hline P. carotovora & 495 & Carrot & & $\begin{array}{l}\text { American Type Culture } \\
\text { Collection }\end{array}$ \\
\hline P. carotovora & A- 8 & Radish & 1971 & Schaad, Orlando, Fla. \\
\hline Erwinia rubrifaciens & 533 (ICPB 103) & Persian walnut & 1963 & Wilson, California \\
\hline E. rubrifaciens & 540 (ICPB 104) & Persian walnut & 1965 & Wilson, California \\
\hline E. rubrifaciens & $602-\mathrm{C}(\mathrm{ICPB} 105)$ & Persian walnut & 1966 & Wilson, California \\
\hline E. rubrifaciens & $605-C$ & Persian walnut & 1967 & Schaad, California \\
\hline E. rubrifaciens & 613 & Persian walnut & 1968 & Schaad, California \\
\hline E. rubrifaciens & 668 & Persian walnut & 1970 & Schaad, California \\
\hline $\begin{array}{l}\text { Enterobacter agglomerans } \\
(\text { Erwinia herbicola })\end{array}$ & $4524-71$ & Human & & Ewing, CDC \\
\hline Xanthomonas campestris & $\mathrm{BBs}$ & Brussels sprout & & Grogan, California \\
\hline$X$. campestris & B24 & Broccoli & 1972 & Moore, Oregon \\
\hline$X$. vesicatoria & $\mathrm{B} 201$ & Tomato & 1971 & Schaad, Sarasota, Fla. \\
\hline Pseudomonas syringae & B-3 & Peach & & English, California \\
\hline$P$. marginalis & 10844 & Lettuce & & $\begin{array}{l}\text { American Type Culture } \\
\text { Collection }\end{array}$ \\
\hline Staphylococcus epidermidis & 14990 (ATCC) & Human & & Roach Diagnostic Lab \\
\hline
\end{tabular}

${ }^{a}$ ATCC, American Type Culture Collection, Rockville, Md.; CDC, Center for Disease Control, Atlanta, Ga.; ICPB, International Collection of Phy topathogenic Bacteria, Univ. of California, Davis, Calif. 
(Tris) (Sigma Chemical Co.), 0.05 M KCI, $0.005 \mathrm{M}$ $\left.\mathrm{MgCl}_{2}\right]$ at $\mathrm{pH}$ 7.4. Deoxyribonuclease was added to a final concentration of $2 \mathrm{mg} / \mathrm{ml}$, and the cells were extracted three times at $2,000 \mathrm{lb} /$ in. $^{2}$ under nitrogen in a Parr disruption bomb (Parr Instr. Co.). Cell debris was removed by centrifugation in a Sorvall SS34 rotor at $12,000 \mathrm{rpm}$ for $20 \mathrm{~min}$.

Intact ribosomes were obtained from the low-speed supernatant by centrifuging at $30,000 \mathrm{rpm}$ in a Spinco 30 rotor for $2 \mathrm{~h}$. The pellets were resuspended overnight at $2 \mathrm{C}$ in $5 \mathrm{ml}$ of $\mathrm{TNM} / 3$ buffer $(0.01 \mathrm{M}$ Tris, $0.5 \mathrm{M} \mathrm{NH} \mathrm{NH}_{4} \mathrm{Cl}, 0.005 \mathrm{M} \mathrm{MgCl}_{2}$ ) at $\mathrm{pH} 7.4$, pooled, and centrifuged at $12,000 \mathrm{rpm}$. Ribosomes in the supernatant were concentrated by centrifuging at $36,000 \mathrm{rpm}$ in a Spinco 40 rotor for $4 \mathrm{~h}$. The sedimented ribosomes were resuspended in TKM/3 buffer, pooled, and centrifuged at $12,000 \mathrm{rpm}$. The spectra at 235,260 , and $280 \mathrm{~nm}$ were measured, and the ribosomes were stored frozen in TKM $/ 3$ buffer.

Washed $70 \mathrm{~S}$ ribosomes were obtained by placing $100 \mathrm{U}$ (absorption at $260 \mathrm{~nm}$ ) of intact ribosomes (freshly extracted) onto 10 to $30 \%$ linear sucrose TKM/3 gradients and centrifuging for $4 \mathrm{~h}$ at 21,000 $\mathrm{rpm}$ using a Spinco SW25.1 rotor. The $70 S$ ribosomes were removed with an Isco gradient collector, pooled, diluted 1:1 with TKM/3 buffer, and centrifuged at $27,000 \mathrm{rpm}$ in a Spinco 30 rotor for $4 \mathrm{~h}$. The sedimented ribosomes were suspended in $\mathrm{TKM} / 3$ and were stored frozen after the absorption spectra were measured.

Highly purified $50 S$ subunits were obtained by dialyzing intact ribosomes against TKM $/ 4\left(3 \times 10^{-4} \mathrm{M}\right.$ $\mathrm{MgCl}$ ) buffer for $24 \mathrm{~h}$. One hundred units of the dialysate were then layered onto 10 to $30 \%$ linear sucrose TKM/4 $\left(10^{-4} \mathrm{M} \mathrm{MgCl}\right)$ gradients and centrifuged for $15.5 \mathrm{~h}$ at $19,500 \mathrm{rpm}$ using a Spinco SW25.1 rotor. The fractions containing the $50 S$ subunits were removed with a Isco gradient collector, pooled, diluted 1:1 with TKM $/ 4$ buffer, and centrifuged in a Spinco 30 rotor for $4 \mathrm{~h}$ at $27,000 \mathrm{rpm}$. The sedimented subunits were resuspended in TKM/4 buffer, the absorption spectra were measured, and the suspension stored frozen.

Crude ribosomes were extracted as above but from cells grown in $250-\mathrm{ml}$ lots. The resuspended cells $(0.1$ to $0.2 \mathrm{~g}$ ) were disrupted at 5 to $10 \mathrm{C}$ for $2 \mathrm{~min}$ with a Bronwill Biosonik III at an intensity setting of 60 . The suspension was then centrifuged at $12,000 \mathrm{rpm}$ in a Sorvall RC2-B centrifuge with a SS34 rotor, the supernatant was removed, and the ribosomes were pelleted by centrifuging at $36,000 \mathrm{rpm}$ in a Spinco 40 rotor for $2 \mathrm{~h}$. The ribosomes were resuspended overnight in $2 \mathrm{ml}$ of TKM/3 buffer, whereupon the suspension was clarified by a centrifugation at 12,000 $\mathrm{rpm}$ and stored frozen after the absorption spectra were measured. Crude ribosomes typically had a $260 / 235$ ratio of 1.60 , whereas the washed ribosomes had a ratio of 1.85 .

Extraction of ribosomal protein. Ribosomal proteins were prepared from $50 S$ subunits suspended in TKM $/ 4$ buffer by the chilled acetic acid method of Hardy et al. (17). The freeze-dried proteins were stored in a desiccator at $-40 \mathrm{C}$.

Gel electrophoresis of subunit proteins. Disc gel electrophoresis of ribosomal proteins in $7.5 \%$ polyacrylamide gels at $\mathrm{pH} 4.3$ was carried out as described previously (19), but with a Buchler Polyanalyst. Five micrograms of protein was used in each electrophoretic run.

Analysis of protein bands. The positions of the stained protein bands in the gel were recorded by scanning the gel at $560 \mathrm{~nm}$ using a $0.05-\mathrm{mm}$ slit width in a Gilford Linear Transport attached to a Beckman DU monochromator and a Gilford model 222 photometer.

Immunology. Washed ribosomes were emulsified $1: 1$ (vol/vol) with Freund incomplete adjuvant (Difco), and rabbits were injected intraperitoneally with 1 to $1.5 \mathrm{mg}$ of ribosomes five times at 10-day intervals. The concentration of ribosomes was based on a specific extinction coefficient of 157 for a $1 \%$. solution at $260 \mathrm{~nm}(42)$. A booster injection was given 7 days after bleeding if the titer was less than 512 . The total amount of antigen injected into the rabbit over the whole immunization period was 6 to $10.0 \mathrm{mg}$. Rabbits were bled 7 days after the last injection and, if needed, 7 days after the booster injection. Antisera were stored at $-20 \mathrm{C}$.

Titrations were performed in $0.5-\mathrm{ml}$ test tubes. Eleven replicate twofold dilutions of each normal serum and of each antiserum were prepared in a final volume of $0.25 \mathrm{ml}$. Incubation was at $37 \mathrm{C}$ and observation for agglutination was made after 4 and 18 $h$. The end point of each titration was defined as the highest dilution with a precipitation on the bottom of the tube.

For Ouchterlony double-diffusion experiments, $0.75 \mathrm{~g}$ of purified agar (Difco), $0.02 \mathrm{~g}$ of sodium azide, $0.85 \mathrm{~g}$ of $\mathrm{NaCl}, 2.0 \mathrm{~g}$ of $\mathrm{MgCl}_{2}$, and $1.0 \mathrm{~g}$ of Trypan blue were dissolved in $100 \mathrm{ml}$ of distilled water, and the mixture was autoclaved. A $10-\mathrm{ml}$ amount of the melted agar was added to each $88-\mathrm{mm}$ diameter plastic petri plate. The distance from the edge of the central well to the surrounding wells was $11 \mathrm{~mm}$. In all experiments unless stated otherwise, the center well contained 5 to $20 \mu$ liters of undiluted normal serum or antiserum, and the outer wells contained 10 to 20 $\mu$ liters of antigen. Antigens consisted of intact or crude ribosomes and were adjusted to $3 \mathrm{mg} / \mathrm{ml}$. The optimal antigen-antibody concentrations were determined by the diffusion method of Piazzi (29). The plates were incubated in a moist chamber at $8 \mathrm{C}$ and observed after $72 \mathrm{~h}$.

In tabulating double-immunodiffusion patterns, only the specific antigen precipitin line (see Table 4) was scored as complete identity $(++)$. For the nonspecific precipitin line (see Table 3), no distinction was made between reactions of identity and partial identity; both are recorded as " + ."

\section{RESULTS}

Disc gel electrophoresis. The Enterobacteriaceae strains studied had similar over-all profiles in that the protein bands were clustered into two major groups and a minor group (Fig. 1 and 2). The first group had four to five distinct bands, and the second group had three to five bands, separated from the first by a conspicuous space. A minor group of weakly stained diffuse bands occupied the lower third of the gel. The results showing that the strains of $E$. 


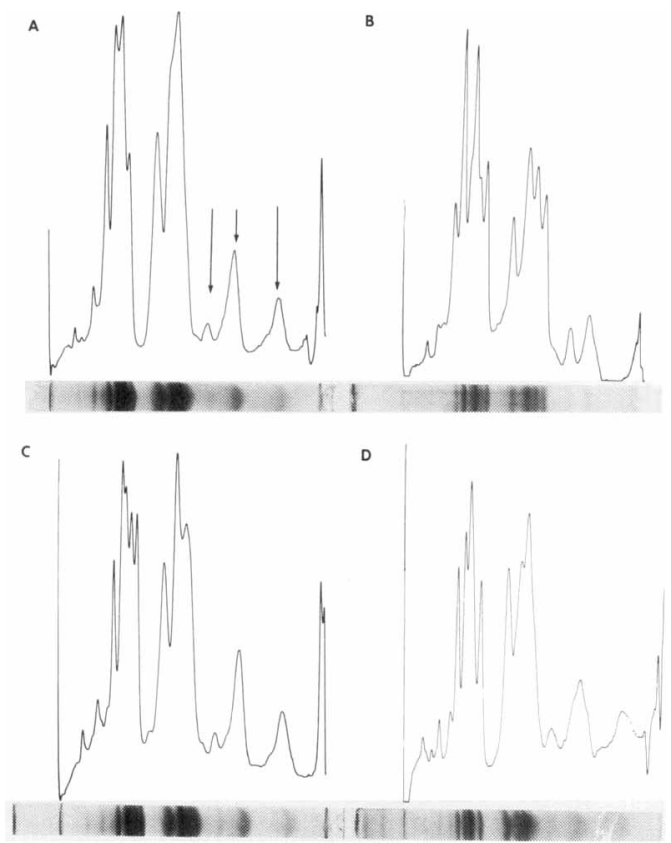

FIG. 1. Comparative gel scans and corresponding acrylamide gels of $50 \mathrm{~S}$ ribosomal proteins from strains of four enterobacteria genera: (A) Salmonella typhimurium, (B) Klebsiella pneumoniae, (C) Escherichia coli $01 a$, and (D) Enterobacter agglomerans (Erwinia herbicola). Arrows denote the three apparently common enterobacteria bands.
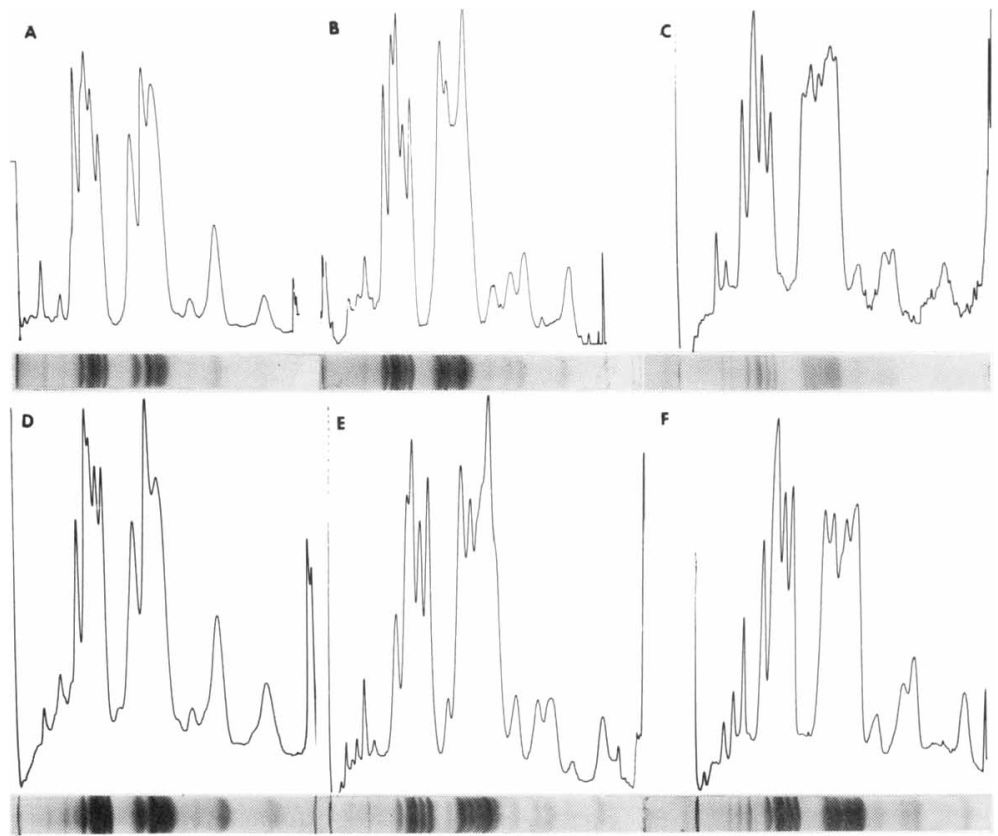

FIG. 2. Comparative gel scans and corresponding acrylamide gels of $50 S$ ribosomal proteins from several enterobacteria strains: (A) Escherichia coli 01a, (D) E. coli 04, (B) Pectobacterium carotovora 105, (E) P. carotovora 150, (C) Erwinia rubrifaciens 540, (F) E. rubrifaciens 533. Note the similarities in the faster-migrating bands (to the right) of each isolate pair.

coli and Salmonella typhimurium had very similar $50 S$ ribosomal protein profiles agreed with the results of others $(25,26)$.

Profiles from two strains each of $E$. coli (Fig. 2A, D), Pectobacterium carotovora (Fig. 2B, E), and Erwinia rubrifaciens (Fig. 2C, F) illustrate profile similarities and differences between the strains. For example, there were minor variations in the uppermost group of bands of $E$. coli strains 01 a (A) and 04 (D). Even greater differences were present in the second group of bands of $P$. carotovora strains 105 (B) and 150 (E). These minor differences did not represent reproducible differences and therefore are not of any comparative value. Such minor variations also occurred from time to time in different electrophoretic runs of the same protein sample. For these reasons it was not possible to make accurate comparisons between different strains or species on the basis of individual bands within the two major band groups. On the other hand, the data suggested that similarities and differences exist between the enterobacteria with respect to the minor group of weakly stained, diffuse bands. $S$. typhimurium (Fig. 1A), Klebsiella pneumoniae (Fig. 1B), E. coli (Fig. 1C), and Enterobacter agglomerans (Fig. 1D) profiles were nearly identical in that each had three clearly resolved bands (arrows, Fig. 1A). Strains of plant origin, $P$. carotovora 150 (Fig. $2 \mathrm{~B}, \mathrm{E})$ and E. rubri-

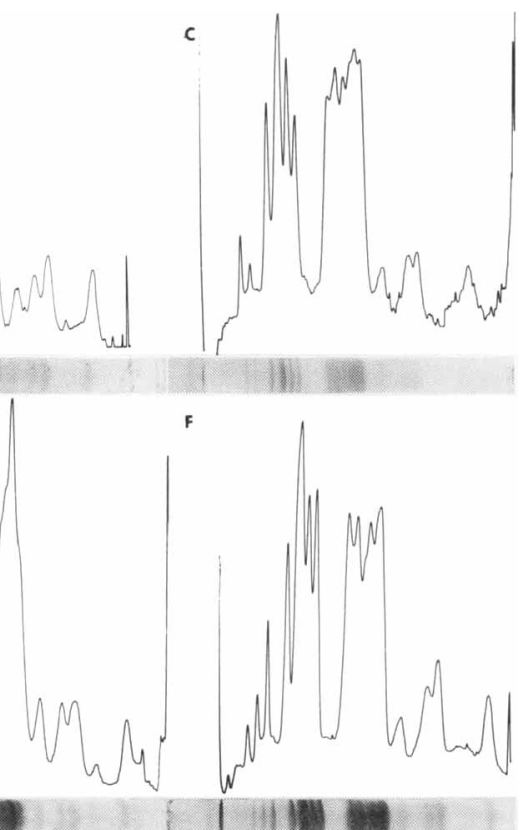


faciens 533 (Fig. 2C, F), also had nearly identical profiles. There were, however, clear differences between the two groups of organisms. Whereas the strains of animal origin had only three bands, those of plant origin had five clearly resolved bands.

To determine whether an organism unrelated to the Enterobacteriaceae might also have similar profiles, several strains belonging to the family Pseudomonadaceae were analyzed. The results showed that Xanthomonas vesicatoria (Fig. 3A), Xanthomonas campestris (Fig. 3C), Pseudomonas marginalis (Fig. 3B), and Pseudomonas syringae (Fig. 3D) indeed had over-all profiles which were similar to those of members of the family Enterobacteriaceae. In addition, the lower diffuse bands which appeared useful in differentiating the plant and animal enterobacteria were also somewhat similar. There was, however, a striking difference with respect to the area between the two major groups of bands. Whereas the enterobacteria profiles were void of any band between the two major band groups, the pseudomonad profiles contained one to two additional clearly resolved bands (Fig. 3).

Immunology. Ribosome preparations derived from the 25 enterobacteria and 4 non-enterobacteria strains were analyzed by Ouchterlony double diffusion against antisera to purified ribosomes of 7 enterobacteria and one non-enterobacterium (see Tables 3 and 4). Homologous systems produced one to three precipitin

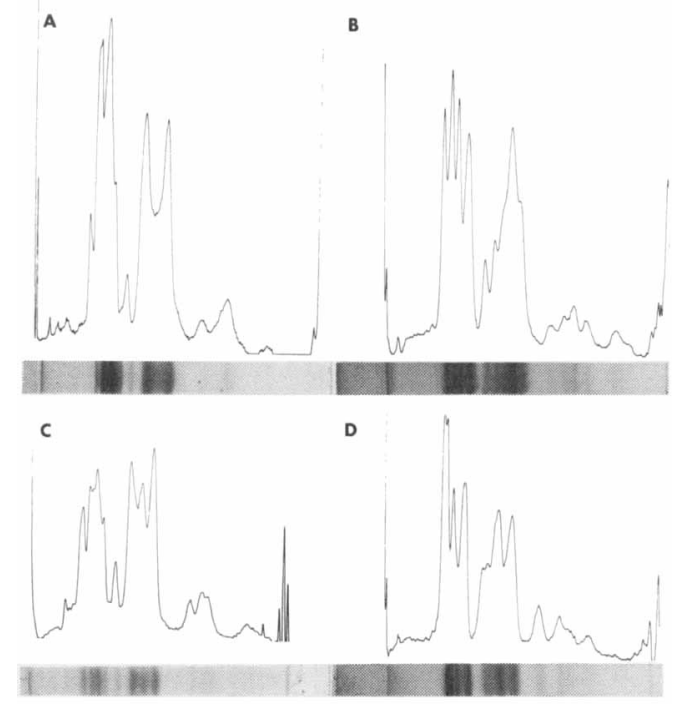

FIG. 3. Gel scan and corresponding acrylamide gel of $50 \mathrm{~S}$ ribosomal proteins of four members of the family Pseudomonadaceae: (A) Xanthomonas vesicatoria, (B) Pseudomonas marginalis, (C) Xanthomonas campestris, and (D) Pseudomonas syringae.
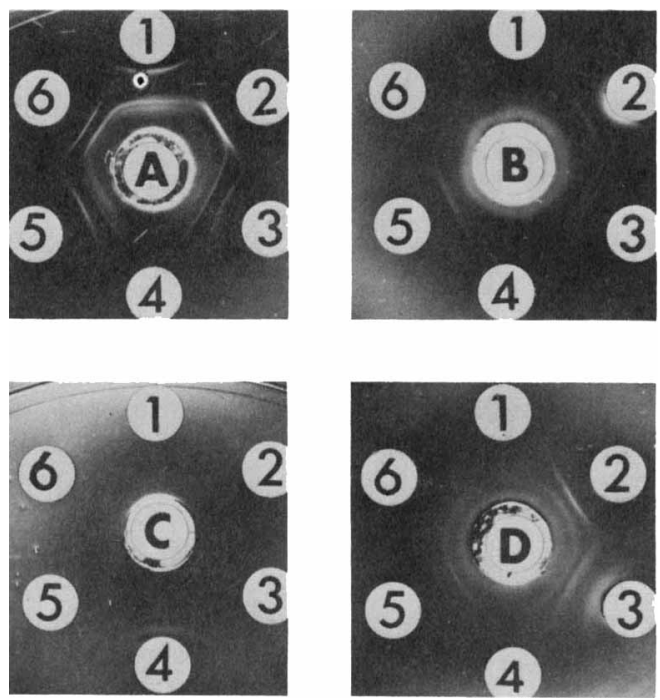

FIG. 4. Ouchterlony double-diffusion patterns of ribosomes from (1) Escherichia coli 01a, (2) Salmonella typhimurium 13311, (3) Erwinia rubrifaciens 533, (4) Xanthomonas campestris BBs, (5) Pectobacterium carotovora 150, and (6) Klebsiella pneumoniae 20. Center wells contained antiserum to ribosomes of (A) E. coli 01a, (B) S. typhimurium 13311, (C) $X$. campestris, and (D) E. rubrifaciens.

lines (Fig. 4). The precipitin which occurred as a single line near the antigen well, hereafter referred to as R-1 antigen, was specific at the subspecies level, whereas the precipitin which occurred as one to several lines midway between the two wells, hereafter referred to as the R-2 antigen, was common to most of the enterobacteria (Fig. 4). When antigens were crudely extracted, no additional lines occurred, and in no case did a line occur between antisera and concentrated high-speed supernatants.

To determine whether the R-1 and R-2 antigens were proteins or ribonucleic acid, 0.3 $\mathrm{mg}$ of ribosomes was treated separately with 10 $\mu \mathrm{g}$ of trypsin and pancreatic ribonuclease for 48 $h$ at $24 \mathrm{C}$. In addition, ribosomes were incubated at $90 \mathrm{C}$ for $1 \mathrm{~h}$. The results of testing treated ribosome preparations of $E$. coli, $S$. typhimurium, $K$. pneumoniae, $P$. carotovora, and Erwinia rubrifaciens are given in Table 2, and typical Ouchterlony gel-diffusion tests are shown in Fig. 5. It was apparent that the topography of these ribosomes was not universal but varied with the species. For example, with respect to the R-1 determinant, $E$. coli (Fig. 5A) was sensitive to trypsin and heat but not to ribonuclease; $P$. carotovora (Fig. $5 \mathrm{C}$ ) was sensitive to all three treatments; and $S$. typhimurium (Fig. 5B) and Erwinia rubrifaciens were insensitive to all three treatments.

The R-2 determinant was responsible for 
TABLE 2. Characterization of antigenic determinants $R-1$ and $R \cdot 2^{a}$

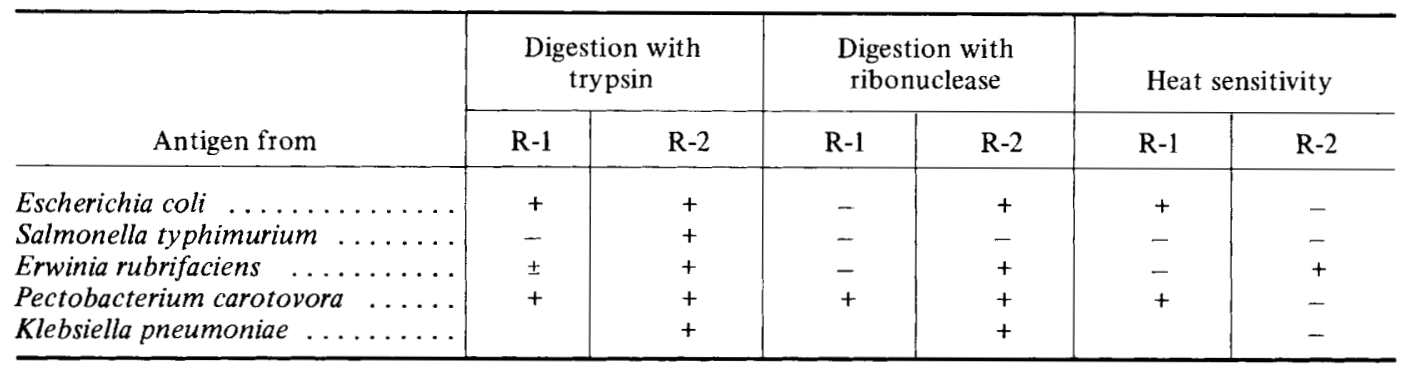

${ }^{a}$ Symbols: + , precipitin line absent in homologous Ouchterlony double-diffusion tests; \pm , weak line of precipitin; -, precipitin line present. Precipitin was scored as stated in Materials and Methods.
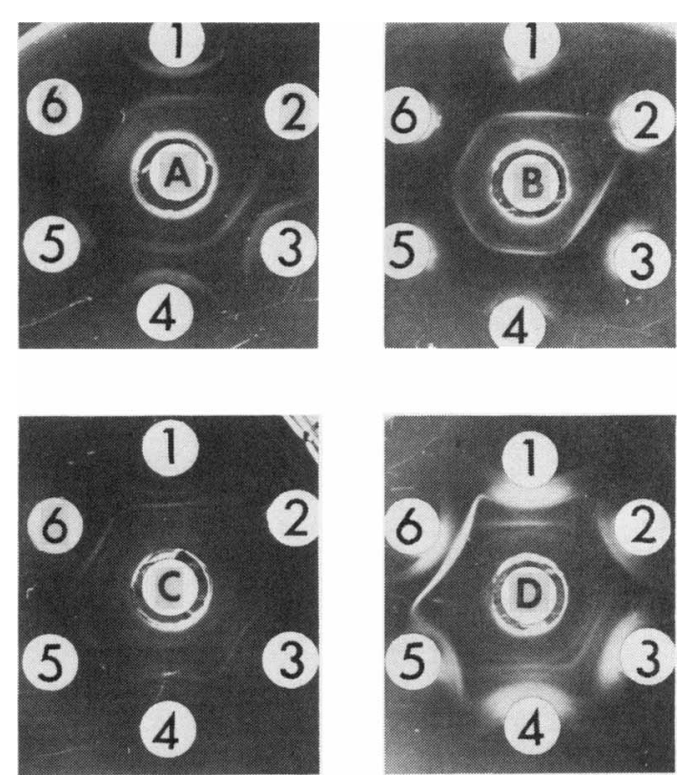

FIG. 5. Immunological reactions of $R-1$ and $R \cdot 2$ antigenic determinants after pretreatment of ribosomes with trypsin, ribonuclease, and heat. Center wells contained antiserum to ribosomes of $(A)$ Escherichia coli, (B) Salmonella typhimurium, (C) Pectobacterium carotovora, and (D) Erwinia rubrifaciens. Outer wells in each pattern contained homologous ribosomes (I, 3, and 4) untreated, (2) trypsin treated, (5) ribonuclease treated, and (6) heat treated.

cross-reactions between most all enterobacteria strains tested. Whereas antisera to the seven enterobacteria isolates reacted against most enterobacteria ribosome preparations, no reaction occurred against ribosomes from three gram-negative rods and a gram-positive coccus (Table 3). However, due to the absence or weakness of the $R-2$ reaction between some enterobacteria systems, the usefulness of this antigen must await further investigations.

On the contrary, reactions of the R-1 determinant were highly consistent. A line of precipitin always occurred between homolo- gous systems, with the exception of $K$. pneumoniae. In no case did the $\mathrm{R}-1$ reaction occur between antiserum to ribosomes of one genus or species and ribosomes of a different genus or species (Table 4 and Fig. 4). To determine the heterogeneity of the R-1 determinant at the subspecies level, ribosomes from several isolates of four different species were compared.

E. coli. Six $E$. coli isolates, each representing a different somatic antigen group, were chosen so that comparisons could be made with a known taxonomic scheme. Antigen for injection was obtained from isolate $01 \mathrm{a}$; intact ribosomes were from 0la, 04, and 06; and crude ribosomes were from $01 \mathrm{~b}, 02$, and $02 \mathrm{~b}$. The results showed that a precipitin line identical to that of the homologous system occurred only with $01 \mathrm{~b}$ ribosomes. No $\mathrm{R}-1$ reaction occurred with ribosomes from any of the other strains (Fig. 6A). These results indicate that the R-1 determinant is subspecies specific and appears to parallel differences in somatic antigens.

S. typhimurium. Ribosomes from two $S$. typhimurium isolates and one Salmonella cholerae-suis isolate (Table 1) were tested against a single antiserum to $S$. typhimurium ribosomes. An identical line of precipitin occurred with both $S$. typhimurium strains, whereas no reaction occurred with ribosomes from $S$. cholerae-suis (Fig. 6B).

P. carotovora. Antigens from isolates 34 and 150 were used for injection, and four additional isolates (Table 1) were used for antigens. The results showed that only in the homologous system did an $R-1$ reaction occur (Table 4 and Fig. 6C). These results suggest that $P$. carotovora, like $E$. coli, has a highly evolved R-1 determinant or that the strains, even though pectolytic, may not belong to $P$. carotovora.

E. rubrifaciens. Two isolates (533 and 540) were used to prepare antisera. When intact ribosomes from cultures 533, 540, and 602-C were tested against either antiserum, identical lines of precipitin occurred. To test this apparent homogeneity among strains, crude 
INT. J. SYST. BACTERIOL.

TABLE 3. Reactions of the R-2 determinant as detected by Ouchterlony immunodiffusion ${ }^{a}$

\begin{tabular}{|c|c|c|c|c|c|c|c|}
\hline \multirow[b]{3}{*}{ Ribosomes from } & \multicolumn{7}{|c|}{ Ribosomal antisera } \\
\hline & \multirow{2}{*}{$\begin{array}{c}\begin{array}{c}\text { Esche- } \\
\text { richia } \\
\text { coli }\end{array} \\
01 \mathrm{a}\end{array}$} & \multirow{2}{*}{$\begin{array}{c}\begin{array}{c}\text { Salmo- } \\
\text { nella } \\
\text { typhi- } \\
\text { murium }\end{array} \\
13311\end{array}$} & \multirow{2}{*}{$\begin{array}{c}\begin{array}{c}\text { Klebsiella } \\
\text { pneumoniae }\end{array} \\
20\end{array}$} & \multicolumn{2}{|c|}{$\begin{array}{l}\text { Pectobacterium } \\
\text { carotovora }\end{array}$} & \multirow{2}{*}{$\begin{array}{c}\begin{array}{c}\text { Erwinia } \\
\text { rubri- } \\
\text { faciens }\end{array} \\
533\end{array}$} & \multirow{2}{*}{$\begin{array}{c}\begin{array}{c}\text { Xantho- } \\
\text { monas } \\
\text { campestri }\end{array} \\
\text { BBs }\end{array}$} \\
\hline & & & & 34 & 150 & & \\
\hline Escherichia coli $01 \mathrm{a}$ & + & + & + & + & + & + & - \\
\hline E. coli $01 \mathrm{~b}$ & + & - & + & + & + & + & - \\
\hline E. coli $02 \mathrm{a}$ & + & - & + & & - & + & - \\
\hline E. coli $02 \mathrm{~b}$ & + & - & + & & - & + & - \\
\hline E. coli 04 & + & - & + & + & + & - & - \\
\hline E. coli 06 & + & - & + & + & - & - & - \\
\hline $\begin{array}{l}\text { Salmonella typhi- } \\
\text { murium } 13311\end{array}$ & + & + & + & + & + & + & - \\
\hline $\begin{array}{l}\text { S. typhi- } \\
\quad \text { murium } 4066\end{array}$ & + & + & - & & + & + & - \\
\hline S. cholerae-suis & + & + & + & & + & + & - \\
\hline Klebsiella pneumoniae 15 & + & - & + & + & + & - & - \\
\hline K. pneumoniae 20 & + & + & - & - & - & + & - \\
\hline K. pneumoniae 30 & + & - & + & + & - & - & - \\
\hline $\begin{array}{r}\text { Pectobacterium } \\
\text { carotovora } 34\end{array}$ & + & - & + & + & - & - & - \\
\hline P. carotovora 14 & + & - & + & + & + & + & - \\
\hline P. carotovora 105 & + & + & + & + & - & - & - \\
\hline P. carotovora 150 & + & + & + & + & + & + & - \\
\hline P. carotovora 495 & + & - & - & - & + & + & - \\
\hline P. carotovora A-8 & + & + & - & + & - & - & - \\
\hline Erwinia rubrifaciens 533 & + & + & + & & + & + & - \\
\hline E. rubrifaciens 540 & + & + & + & & + & + & - \\
\hline E. rubrifaciens $602-\mathrm{C}$ & + & + & + & + & - & + & - \\
\hline E. rubrifaciens $605-\mathrm{C}$ & + & + & + & & + & + & - \\
\hline E. rubrifaciens 613 & + & - & - & & - & + & - \\
\hline E. rubrifaciens 668 & + & + & + & & + & + & - \\
\hline Xanthomonas campestris BBs & - & - & - & - & - & - & + \\
\hline$X$. campestris $\mathrm{B}-24$ & - & - & - & - & - & - & + \\
\hline Pseudomonas syringae B-3 & - & - & - & - & - & - & - \\
\hline $\begin{array}{l}\text { Staphylococcus } \\
\text { epidermidis } 14990\end{array}$ & - & - & - & - & - & - & - \\
\hline
\end{tabular}

$a+$, Reaction of identity or partial identity; - , no reaction.

extracts from three additional isolates (Table 1) were obtained. These isolates also gave identical lines of precipitin when tested against antiserum to 540 (Fig. 6D) or 533 ribosomes. These results are in contrast to those obtained with $E$. coli and $P$. carotovora and may indicate a highly conserved ribosomal genome in $E$. rubrifaciens.

\section{DISCUSSION}

The data presented above show that the analysis of $50 S$ ribosomal subunit proteins by disc gel electrophoresis and $70 S$ ribosomes by Ouchterlony double-diffusion have certain values and limitations as taxonomic tools. Whereas the gel electrophoresis data varied somewhat 
and were difficult to interpret, the immunological data were consistent and required little explanation. That immunodiffusion was found to be more sensitive than gel electrophoresis was not entirely unexpected. It is known, for example, that immunodiffusion can detect a $4.0 \%$ divergence in an amino acid sequence (30).

Disc gel electrophoresis. The electrophoresis data failed to differentiate clearly the closely related $E$. coli, $S$. typhimurium, $K$. pneumoniae, and Enterobacter agglomerans. Whether this failure was due to inadequate resolution of certain proteins or a true similarity in the size and charge of $50 \mathrm{~S}$ ribosomal proteins of different species is not known. The data did, however, suggest that enterobacteria could be differentiated according to animal or plant

TABLE 4. Reactions of the R-1 determinant as detected by Ouchterlony immunodiffusion ${ }^{a}$

\begin{tabular}{|c|c|c|c|c|c|c|c|c|}
\hline \multirow[b]{3}{*}{ Ribosomes from } & \multicolumn{8}{|c|}{ Ribosomal antisera } \\
\hline & \multirow{2}{*}{$\begin{array}{c}\begin{array}{c}\text { Esche- } \\
\text { richia } \\
\text { coli }\end{array} \\
01 \mathrm{a}\end{array}$} & \multirow{2}{*}{$\begin{array}{c}\begin{array}{c}\text { Salmo- } \\
\text { nella } \\
\text { typhi- } \\
\text { murium }\end{array} \\
13311\end{array}$} & \multirow{2}{*}{$\begin{array}{c}\begin{array}{c}\text { Klebsiella } \\
\text { pneumoniae }\end{array} \\
20\end{array}$} & \multicolumn{2}{|c|}{$\begin{array}{l}\text { Pectobacterium } \\
\text { carotovora }\end{array}$} & \multicolumn{2}{|c|}{$\begin{array}{c}\text { Erwinia } \\
\text { rubrifaciens }\end{array}$} & \multirow{2}{*}{$\begin{array}{c}\text { Xantho- } \\
\text { monas } \\
\text { campestris } \\
\text { BBs }\end{array}$} \\
\hline & & & & 34 & 150 & 533 & 540 & \\
\hline Escherichia coli $01 \mathrm{a}$ & ++ & - & - & - & - & - & - & - \\
\hline E. coli $01 \mathrm{~b}$ & + & - & - & - & - & - & - & - \\
\hline E. coli $02 \mathrm{a}$ & - & - & - & - & - & - & - & - \\
\hline E. coli $02 \mathrm{~b}$ & - & - & - & - & - & - & - & - \\
\hline E. coli 04 & - & - & - & - & - & - & - & - \\
\hline E. coli 06 & - & - & - & - & - & - & - & - \\
\hline $\begin{array}{l}\text { Salmonella typhi- } \\
\text { murium } 13311\end{array}$ & - & + & - & - & - & - & - & - \\
\hline $\begin{array}{l}\text { S. typhi- } \\
\text { murium } 4066\end{array}$ & - & $H$ & - & - & - & - & - & - \\
\hline S. cholerae-suis & - & - & - & - & - & - & - & - \\
\hline Klebsiella pneumoniae 15 & - & - & - & - & - & - & - & - \\
\hline K. pneumoniae 20 & - & - & - & - & - & - & - & - \\
\hline K. pneumoniae 30 & - & - & - & - & - & - & - & - \\
\hline $\begin{array}{r}\text { Pectobacterium } \\
\text { carotovora } 34\end{array}$ & - & - & - & ++ & - & - & - & - \\
\hline$P$. carotovora 14 & - & - & - & - & - & - & - & - \\
\hline P. carotovora 105 & - & - & - & - & - & - & - & - \\
\hline P. carotovora 150 & - & - & - & - & ++ & - & - & - \\
\hline P. carotovora 495 & - & -- & - & - & - & - & - & - \\
\hline P. carotovora A-8 & - & - & - & - & - & - & - & - \\
\hline Erwinia rubrifaciens 533 & - & - & - & - & - & ++ & ++ & - \\
\hline E. rubrifaciens 540 & - & - & - & - & - & ++ & ++ & - \\
\hline E. rubrifaciens $602-\mathrm{C}$ & - & - & - & - & - & ++ & ++ & - \\
\hline E. rubrifaciens $605-\mathrm{C}$ & - & - & - & - & - & ++ & ++ & - \\
\hline E. rubrifaciens 613 & - & - & - & - & - & ++ & ++ & - \\
\hline E. rubrifaciens 668 & - & - & - & - & - & ++ & ++ & - \\
\hline $\begin{array}{l}\text { Xanthomonas cam- } \\
\text { pestris } \mathrm{BBs}\end{array}$ & - & - & - & - & - & - & - & ++ \\
\hline$X$. campestris B-24 & - & - & - & - & - & - & - & ++ \\
\hline Pseudomonas syringae $\mathrm{B}-3$ & - & - & - & - & - & - & - & - \\
\hline $\begin{array}{l}\text { Staphylococcus } \\
\quad \text { epidermidis } 14990\end{array}$ & - & - & - & - & - & - & - & - \\
\hline
\end{tabular}

${ }^{a}++$, Complete identity; - , no reaction; partial identity reaction $(+)$ not observed. 

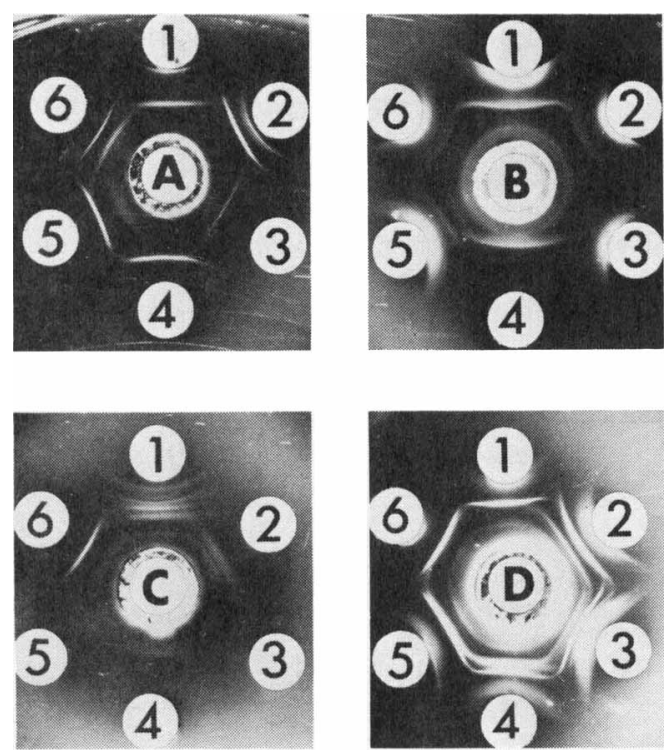

FIG. 6. Immunodiffusion reactions of ribosomes from several isolates of the same species. Center well contained antiserum to ribosomes from: (A) Escherichia coli 01a, (B) Salmonella typhimurium 13311, (C) Pectobacterium carotovora 150, and (D) Erwinia rubrifaciens 540. Outer wells of $A$ contained ribosomes from (1) E. coli 01a, (2) $01 b$, (3) 06, (4) $02 b$, (5) $02 a$, and (6) 04. Outer wells of $B$ contained ribosomes from $S$. typhimurium: (1) 13311, (2) 13311 , (3) 4066, (5) 4066, and (6) 13311. Well 4 of $B$ contained ribosomes from Salmonella cholerae-suis. Outer wells of $C$ contained ribosomes from $P$. carotovora: (1) 150, (2) 14, (3) 34, (4) 105, (5) 495, and (6) A-8. Outer wells of $D$ contained ribosomes from E. rubrifaciens: (1) 540 , (2) 533, (3) 602-C, (4) $605-C$, (5) 613, and (6) 668.

origin. Both plant pathogenic organisms studied had two additional faster-migrating proteins. These differences were sufficiently large and reproducible to warrant further investigations to determine whether these particular proteins might serve to differentiate plant and animal enterobacteria. There were minor differences in profiles of different strains, but these differences were not reproducible and therefore were not considered to be taxonomically valuable.

Even though profiles of several strains of a different family were distinguishable from enterobacteria profiles, all had similar over-all profiles. These results conflict with earlier results which showed that ribosomal proteins of erwiniae distributed into definitive over-all patterns which did not exist in strains of a different family (19).

Several researchers $(19,26,27)$ have suggested that acrylamide gel electrophoresis of ribosomal proteins might be a useful taxonomic tool. The results here suggest that disc gel electrophoresis data of $50 S$ ribosomal proteins alone are not adequate taxonomic criteria. On the contrary, the data suggest that ribosomal proteins of similar size and charge may exist among unrelated organisms. Even if small differences in protein size and charge could be measured statistically, the taxonomic significance of such small differences would be doubtful. More research is needed to identify each protein band. For example, the use of specific $50 S$ antiribosomal protein(s) in combination with gel profiles might allow more accurate gel comparisons.

Immunology. Ribosomes of most of the strains tested had two immunogenic determinants: one specific at the subspecies level, designated $\mathrm{R}-1$, and one partially specific at the family level, designated R-2. Whereas the R-2 determinant was of questionable taxonomic value because of inconsistencies and variability, the $\mathrm{R}-1$ determinant was extremely reliable and was either present or absent. The failure of ribosomes of one strain to react with antiserum to ribosomes of a strain from a different species demonstrates the unique specificity of ribosomal topography.

Research into the specificity of ribosomal topography is recent, and the results sometimes conflict. Ribosomes were first thought to be immunogenically species specific $(14,31)$; however, subsequent investigations have shown otherwise. For example, antisera to $E$. coli ribosomal proteins cross-reacted with ribosomal proteins of Neurospora crassa $(1,32)$. Also, antisera to ribosomes of $E$. coli, their subunits, core particles, or split protein reacted as strongly with Proteus, Salmonella, or Serratia ribosomes as in the homologous system and to a lesser degree even with ribosomes from Azotobacter, Lactobacillus, or Sarcina strains (49). With the exception of a positive reaction between mouse and chicken ribosomes, Noll and Bielka (24) found that intact ribosomes from different animal tissues reacted only with homologous antisera. The discovery by Noll and Bielka that ribosome structure was more specific than extracted proteins may explain some of the discrepancies in the literature. I have found that intact ribosomes are not specific at the species level as suggested by Noll and Bielka but instead are specific at the subspecies level. My results agree favorably with molecular genetic studies that used several of the same isolates. For example, using deoxyribonucleic acid (DNA) relatedness, Brenner et al. (3) found a $17 \%$ divergence in the DNAs of $E$. coli 01 a and 02 a. Since I found that $E$. coli 
$01 \mathrm{a}$ and $02 \mathrm{a}$ ribosomes did not react specifically, one could conclude that ribosome immunology is capable of detecting a DNA divergence of less than $17 \%$. The lack of immunological relatedness between the six $P$. carotovora isolates agrees with the confused taxonomy of this species (16) and with the finding that $P$. carotovora has a guanine plus cytosine $(\mathrm{G}: \mathrm{C})$ base ratio which ranges from 51.0 to 54.0 (38). However, another interpretation could be that all the isolates studied were not $P$. carotovora. Finally, the immunological identity of the six E. rubrifaciens strains agrees with the biochemical homogeneity of $E$. rubrifaciens (Ewing, personal communication) and also with other genetic data. It has been reported that isolates 533, 540, and $602-C$ have a $\mathrm{G}$ : $\mathrm{C}$ base ratio with a range of less than $0.6 \%$ (38).

That E. rubrifaciens might have a highly conserved genome is also supported by ecological data. E. rubrifaciens was discovered in 1962 (48) and has not been reported outside California. Also, each isolate used in this study was obtained from a different geographic location over a period of 8 years (Table 1 ). In addition, the only known host of $E$. rubrifaciens, Persian walnut, cultivar Hartley, was originally propagated in 1940 and not extensively planted until the 1950's. The apparent limitation within California is supported by an extensive survey conducted in 1970 by C. I. Kado and myself, in cooperation with the Oregon State University Agricultural Extension Service, which included almost all mature Hartley walnut orchards known to exist outside California. Furthermore, the pathogen is limited to the nonfunctional phloem tissue of mature trees; it will not cause a disease in 3-year-old trees nor in primary tissue of mature trees $(33,34)$. Finally, $E$. rubrifaciens is not capable of surviving as a saprophyte (34).

It is suggested that ribosomal topography, as revealed by immunodiffusion, is an excellent indicator of the evolutionary state of an organism. It is suggested further that because of its apparently conserved genome, E. rubrifaciens is an ideal organism for studying the influence environment has on genetic variability of an organism. Finally, ribosomal topography appears to be a more accurate indicator of intraspecific phylogenic relatedness than do individual ribosomal components, such as subunit proteins.

Besides being a valuable taxonomic tool, ribosomal immunology should also help in elucidating the ribosome's topography. Little is known about the structural relationships be- tween ribosomal RNA (rRNA) and protein. Proposals of topographical models of the ribosome suggest a helical rRNA packed with globular molecules of protein (10) or each subunit having an equally exposed protein and RNA moiety (8). The most recent investigations on ribosomal topography show, however, that proteins are more exposed on the $30 S$ subunit (5), whereas the opposite is true for the $50 S$ subunit (6). These contradictory results are in line with the extreme immunogenic heterogeneity found in this study between ribosomes of strains of the same species.

Ribosome immunology may have yet another important application, that is, as an identification tool for diagnostic laboratories. For example, an antiserum for a specific pathogen or a pool of several antisera could be used to obtain a quick identification of an isolate, thereby expediting proper treatment.

\section{ACKNOWLEDGMENTS}

This investigation was supported by National Science Foundation grant GU-3314.

I wish to thank W. H. Ewing for his helpful discussions and suggestions during this investigation, and W. H. Ewing and D. J. Brenner for their critical review of the manuscript. The capable technical assistance of William White is greatly appreciated.

\section{REPRINT REQUESTS}

Address reprint requests to: Dr. N. W. Schaad, University of Georgia, College of Agriculture Experiment Stations, Georgia Station, Experiment, Ga. 30212.

\section{LITERATURE CITED}

1. Alberghina, F. A. M., and S. R. Suskind. 1967. Ribosomes and ribosomal protein from Neurospora crassa. I. Physical, chemical, and immunochemical properties. J. Bacteriol. 94:631-649.

2. Bottone, M. S., and S. Schneierson. 1972. Erwinia species: an emerging human pathogen. Amer. J. Clin. Pathol. 57:400-405.

3. Brenner, D. J., G. R. Fanning, F. J. Skerman, and S. Falkow. 1972. Polynucleotide sequence divergence among strains of Escherichia coli and closely related organisms. J. Bacteriol. 109:953-965.

4. Brenner, D. J., G. R. Fanning, and A. G. Steigerwalt. 1972. Deoxyribonucleic acid relatedness among species of Erwinia and between Erwinia species and other enterobacteria. J. Bacteriol. 110:12-17.

5. Chang, R. N., and J. G. Flacks. 1970. Topography of the Escherichia coli $30 S$ ribosomal subunit and 
streptomycin binding. Proc. Nat. Acad. Sci U.S.A. 67:1321-1328.

6. Chang, R. N., and J. G. Flacks. 1971. Topography of the Escherichia coli ribosome. II. Preliminary sequence of $50 S$ subunit protein attack by trypsin and its correlation with functional activities. J. Mol. Biol. 61:387-400.

7. Chatterjee, A. K., and M. P. Starr. 1972. Genetic transfer of episomic elements among Erwinia species and other enterobacteria: $\mathrm{F}^{\prime} l a c^{+}$. J. Bacteriol. 111:169-176.

8. Cox, R. H., and S. A. Bonnanou. 1969. A possible structure of the rabbit reticulocyte ribosomes. Biochem. J. 114:769-774.

9. Crichton, R. R., and H. G. Wittmann. 1971. Ribosomal proteins. XXIV. Trypsin digestion as a possible probe of the conformation of Escherichia coli ribosomes. Mol. Gen. Genet. 114:95-105.

10. Daya, L., and W. B. Gratzer. 1969. On the association of basic proteins with RNA in ribosomes and artificial complexes. Biochim. Biophys. Acta 179:239-241.

11. Estrup, F., and M. Santer. 1966. Immunological analysis of the proteins of Escherichia coli ribosomes. J. Mol. Biol. 20:447-452.

12. Ewing, W. H., and M. A. Fife. 1972. Enterobacter agglomerans (Beijerinck) comb. nov. (the Herbicola-Lathyri bacteria). Int. J. Syst. Bacteriol. 22:4-11.

13. Fogel, S., and P. S. Sypherd. 1968. Chemical basis for heterogenicity of ribosomal proteins. Proc. Nat. Acad. Sci. U.S.A. 59:1329-1336.

14. Friedman, D. I., J. G. Olenick, and F. E. Hahn. 1968. A $50 S$ ribosomal determinant: immunological studies correlating function and structure. J. Mol. Biol. 32:579-586.

15. von Graeventiz, F., and A. Strouse. 1966 Isolation of Erwinia spp. from human sources. Antonie van Leeuwenhoek J. Microbiol. Serol. 32:429-430.

16. Graham, D. C. 1964. Taxonomy of the soft rot coliform bacteria. Annu. Rev. Phytopathol. 2:13-42.

17. Hardy, E. S., C. G. Kurland, R. Voynow, and G. Mora. 1969 The ribosomal proteins of Esche richia coli. I. Purification of the $30 S$ ribosomal proteins. Biochemistry 8:2897-2900.

18. Huang, J., and P. S. Sypherd. 1972. Comparative chemistry of $30 \mathrm{~S}$ ribosomal proteins of Salmonella typhimurium. J. Bacteriol. 110:300-305.

19. Kado, C. I., N. W. Schaad, and M. Heskett. 1972. Comparative gel electrophoresis studies of ribosomal protein of Erwinia species and members of the Enterobacteriaceae. Phytopathology 62:1077-1082

20. Kaltschmidt, E., and H. G. Wittmann. 1970. Ribosomal proteins. VII. Two-dimensional polyacrylamide gel electrophoresis for fingerprinting of ribosomal proteins. Anal. Biochem. 36:401-412.

21. Leboy, P. S., E. C. Cox, and J. G. Flacks. 1964 The chromosomal site specifying a ribosomal protein in Escherichia coli. Proc. Nat. Acad. Sci. U.S.A. 52:1367-1374

22. Mizushima, S., and M. Nomura. 1970. Assembly mapping of $30 S$ ribosomal proteins from $E$. coli. Nature (London) 226:1214-1218.

23. Muraschi, T. F., M. Friend, and D. Bolles. 1965. Erwinia-like microorganisms isolated from animal and human hosts. Appl. Microbiol. 13:128-131.

24. Noll, F., and H. Bielka, 1970. Studies on proteins of animal ribosomes. III. Immunochemical analyses of ribosomes from different tissues and species of animals. Mol. Gen. Genet. 106:106-113.

25. O'Neil, D. M., and P. S. Sypherd. 1972. Cotransduction of strA and ribosomal protein cistrons in Escherichia coli-Salmonella typhimurium hybrids. J. Bacteriol. 105:947-956.

26. Osawa, S., T. Itoh, and E. Otaka. 1971. Differentiation of ribosomal protein composition in the genus Escherichia coli and its related bacteria. J. Bacteriol. 107:168-178.

27. Otaka, E., T. Itoh, and S. Osawa. 1968. Ribosomal proteins of bacterial cells: strain and species-specificity. J. Mol. Biol. 33:93-107.

28. Petterman, M. 1964. The physical and chemical properties of ribosomes. Elsevier Pub. Co., New York.

29. Piazzi, S. E. 1969. A simple method for preliminary immunodiffusion test of antigen-antibody systems having unknown ratios or reaction. Anal. Biochem. 27:281-284.

30. Prager, E. M., and A. C. Wilson. 1971. The dependence of immunological cross-reaction upon sequence resemblance among lysozymes. II. Comparison of precipitin and micro-complement fixation results. J. Biol. Chem. 246:7010-7017.

31. Quash, G., J. P. Dandeu, E. Barbu, and J. Danjiel. 1962. Recherches preliminaires sur les antigens des ribosomes. Ann. Inst. Pasteur 103:3.

32. Rothschild, H., H. Itikawa, and S. R. Suskind. 1967. Ribosomes and ribosomal proteins from Neurospora crassa. II. Ribosomal protein in different wild-type strains and during various stages of development. J. Bacteriol. 94:1800-1801.

33. Schaad, N. W., and E. E. Wilson. 1970. Pathological anatomy of the bacterial phloem canker disease of Juglans regia L. Can. J. Bot. 48: $1055-1060$.

34. Schaad, N. W., and E. E. Wilson. 1971. The ecology of Erwinia rubrifaciens and the development of phloem canker of Persian walnut. Ann. Appl. Biol. 69:125-136.

35. Shaw, M. V., and R. L. Armstrong. 1972. Biosynthesis of $50 S$ ribosomal proteins during the outgrowth of Bacillus subtilis spores. J. Bacteriol. 109:276-284.

36. Spiegelman, S., and S. A. Yankofsky. 1965. The relation of ribosomal RNA to the genome, p. 537-579. In V. Bryson and H. J. Vogel (ed.), evolving genes and proteins. Academic Press Inc., New York.

37. Spirin, A. S., and L. P. Gaurilova. 1969. The ribosome. Springer-Verlag, New York.

38. Starr, M. P., and M. Mandel. 1969. DNA base composition and taxonomy of phytopathogenic and other enterobacteria. J. Gen. Microbiol. 56:113-123.

39. Stoffler, G., and H. G. Wittmann. 1971. Sequence 
differences of Escherichia coli $30 S$ ribosomal protein as determined by immunochemical methods. Proc. Nat. Acad. Sci. U.S.A. 68:2283-2287.

40. Stoffler, G., and H. G. Wittmann. 1972. Ribosomal proteins. XXV. Immunological studies on Escherichia coli ribosomal proteins. J. Mol. Biol. 62:408-409.

41. Sun, T. T., T. A. Bickle, and R. R. Trout. 1972. Similarity in the size and number of ribosomal proteins from different prokaryotes. J. Bacteriol. 111:424-480.

42. Tissieres, A., J. D. Watson, D. Schlessinger, and B. R. Hollingworth. 1959. Ribonucleoprotein particles from Escherichia coli. J. Mol. Biol. 1:221-233.

43. Traub, T. 1970. Structure, function and in vitro reconstitution of Escherichia coli ribosomes. Curr. Top. Microbiol. Immunol. 52:1-93.

44. Watson, J. D. 1963. Involvement of RNA in the synthesis of proteins. Science 140:17-25.

45. Waldee, E. L. 1945. Comparative studies on some peritrichous-phytopathogenic bacteria. Iowa State Coll. J. Sci. 19:435.

46. Waller, J. P. 1964. Fractionation of the ribosomal protein from Escherichia coli. J. Mol. Biol. 10:319-336.

47. Wechster, A., E. Bottone, and R. Lasser. 1971. Brain abscess caused by an Erwinia species. Amer. J. Med. 51:680-684.

48. Wilson, E. E., F. M. Zeitoun, and D. L. Frederickson. 1967. Bacterial phloem canker, a new disease of Persian walnut trees. Phytopathology 57:618-621.

49. Wittmann, H. G., G. Stoffler, E. Kaltschmidt, V. Rudloff, H. G. Janda, M. Dzionara, D. Donner, K. Nierhaus, M. Cech, I. Rindernach, and B. Wittmann. 1970. Protein, chemical and serological studies on ribosomes of bacteria, yeast, and plants. FEBS Symp. 21:33-46. 